\title{
Nuclear Medicine Program Progress Report for Quarter Ending September 30, 1996
}

\author{
AECEIVED \\ FER 201997 \\ OSTI
}

\author{
F. F. Knapp, Jr. \\ K. R. Ambrose \\ A. L. Beets \\ R. Boll \\ H. Luo \\ D. W. McPherson \\ S. Mirzadeh
}

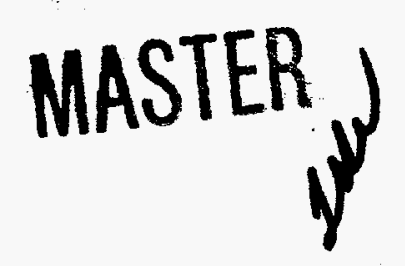

DISTRIBUTON OF THIS DOCUMENT IS UNLMMTED

MANAGED AND OPERATED BY

LOCKHEED MARTN ENERGY RESEAREH CORPORANON FOR THE UNTED STATES

DEPARTIETT OF ENERGY 
This report has been reproduced directly from the best available copy.

Available to DOE and DOE contractors from the Office of Scientific and Technical Information, P. O. Box 62. Oak Ridge. TN 37831; prices available from (423) 576-8401, FTS 626-8401.

Available to the public from the National Technical Information Service, U.S. Department of Commerce. 5285 Port Royal Road, Springfield. VA 22161.

This report was prepared as an account of work sponsored by an agency of the United States Government. Neither the United States Government nor any agency thereof, nor any of their employees, makes any warranty, express or implied, or assumes any legal liability or responsibility for the accuracy, completeness, or usefuiness of any information, apparatus, product, or process disclosed, or represents that its use would not infringe privately owned rights. Reference herein to any specific commercial product, process, or service by trade name. trademark, manufacturer, or otherwise. does not necessarily constitute or imply its endorsement, recommendation, or favoring by the United States Government or any agency thereof. The views and opinions of authors expressed herein do not necessarily state or reflect those of the United States Government of any agency thereof. 


\section{DISCLAIMER}

Portions of this document may be illegible in electronic image products. Images are produced from the best available original document. 
ORNLTM-13336

Contract No. DE-AC05-96OR22464

Health Sciences Research Division

\section{NUCLEAR MEDICINE PROGRAM PROGRESS REPORT \\ FOR QUARTER ENDING September 30, 1996}

F. F. Knapp, Jr.
K. R. Ambrose
H. Luo
A. L. Beets
D. W. McPherson
R. Boll
S. Mirzadeh

Work sponsored by

DOE Office of Health and

Environmental Research

Date Published_January 1997

OAK RIDGE NATIONAL LABORATORY

Oak Ridge, Tennessee 37831-6285 managed by

LOCKHEED MARTIN ENERGY RESEARCH CORPORATION for the

U.S. DEPARTMENT OF ENERGY under contract DE-AC05-960R22464 
Previous reports in this series:

ORNL/TM-5809

ORNL/TM-5936

ORNL/TM-6044

ORNL/TM-6181

ORNL/TM-6371

ORNL/TM-6410

ORNL/TM-6638

ORNL/TM-6639

ORNL/TM-6771

ORNL/TM-6916

ORNL/TM-6958

ORNL/TM-7072

ORNL/TM-7223

ORNL/TM-7411

ORNL/TM-7482

ORNL/TM-7605

ORNL/TM-7685

ORNL/TM-7775

ORNL/TM-7918

ORNL/TM-8123

ORNL/TM-8186

ORNL/TM-8363

ORNL/TM-8428

ORNL/TM-8533

ORNL/TM-8619

ORNL/TM-8746

ORNL/TM-8827

ORNL/TM-8966

ORNL/TM-9037

ORNL/TM-9124

ORNL/TM-9343

ORNL/TM-9394

ORNL/TM-9480

ORNL/TM-9609

ORNL/TM-9707

ORNL/TM-9784

ORNL/TM-9937

ORNL/TM-10082

ORNL/TM-10238

ORNL/TM-10294

ORNL/TM-10377

ORNL/TM-10441

ORNL/TM-10618

ORNL/TM-10711

ORNL/TM-10839

ORNL/TM-11014

ORNL/TM-11043

ORNL/TM-11145

ORNL/TM-11224

ORNL/TM-11304

ORNL/TM-11377

ORNL/TM-11427

ORNL/TM-11550

ORNL/TM-11570

ORNL/TM-11721

ORNL/TM-11755

ORNL/TM-11830

ORNL/TM-11881

ORNL/TM-11992

ORNL/TM-12054

ORNL/TM-12110

ORNL/TM-12159

ORNL/TM-12222

ORNL/TM-12312

ORNL/TM-12343

ORNL/TM-12411

ORNL/TM-12485

ORNL/TM-12661

ORNL/TM-12707

ORNLTM-12789

ORNL/TM-12875

ORNL/TM-12909

ORNL/TM-12965

ORNL/TM-13053

ORNL/TM-13107

ORNL/TM-13150

ORNL/TM-13267

ORNL/TM-13328 
CONTENTS

Summary

5

Evaluation of the Neutron Burn-Up Cross Section of Tungsten-188

6

Literature Cited

13

Other Nuclear Medicine Group Activities

14

Medical Cooperative Programs

14

Distribution of Radioisotopes By Cost Recovery Through the

ORNL Isotopes Distribution Office (IDO)

14

Recent Publications

15

Meetings

15 


\section{SUMMARY}

The reactor production yields of tungsten-188 produced by neutron capture by enriched tungsten-186 in the HFIR and other reactors are nearly an order of magnitude lower than expected by calculation using established cross section values. Since neutron capture of tungsten-188 may be the major factor which significantly reduces the observed yields of tungsten-188, we have evaluated the possible "burn-up" cross section of the tungsten-188 product. Tungsten-189 was produced by irradiating a radioactive target containing a known amount of ${ }^{188} \mathrm{~W}$. In order to reduce the radiation level to an acceptable level $(<20 \%$ detector dead time), we chemically removed $>90 \%$ of ${ }^{188} \mathrm{Re}$, which is the decay product of ${ }^{188} \mathrm{~W}$, prior to irradiation. We were able to confirm the two predominant $y$-rays in the decay of ${ }^{189} \mathrm{~W}, 260.1 \pm 1.4$ and $421.5 \pm 1.6 \mathrm{keV}$. By following the decay of these $\mathrm{y}$-rays in two sets of experiments, a half-life of $10.8 \pm 0.3 \mathrm{~m}$ was obtained for ${ }^{189} \mathrm{~W}$. Based on a knowledge of the ${ }^{188} \mathrm{~W}$ content of target $(52.6 \mathrm{mBq})$, neutron flux of $5 \times 10^{13} \mathrm{n} \cdot \mathrm{s}^{-1} \cdot \mathrm{cm}^{-2}$, irradiation time of $10 \mathrm{~min}$ and with the assumption of $100 \%$ intensity for 260.1 and $421.5 \mathrm{keV} \gamma$-rays, a crosssection of $12.0 \pm 2.5 \mathrm{~b}$ was calculated for burn-up cross-section of ${ }^{188} \mathrm{~W}$, which helps explain the greatly reduced production yields of ${ }^{188} \mathrm{~W}$.

During this period, several radioisotopes, generators and other medical radioisotopes were provided to collaborators for joint research, including tungsten-188/rhenium-188 generators which were provided to the Department of Interventional Cardiology (J. Wienberger, M.D.), Columbia University, New York, and the Department of Nuclear Medicine (J. Kropp, M.D.) at the University Hospital, Dresden, Germany. Platinium-193m was provided to the Clinic for Nuclear Medicine (S. N. Reske, M.D.), The University of Ulm, Germany, for a collaborative project focused on evaluating the kinetics of uptake into ovarian cancer cells refractive to cis-DDP therapy. Medical radioisotopes provided for full cost recovery through the ORNL Isotope Production and Distribution Program included a sample of tungsten-188 provided to Nordion, Inc., and high, specific activity rhenium-186 which was sold to Mallinckrodt Medical, Petten, Holland: A tungsten-188/rhenium188 generator was provided to Altarex, Inc., Alberta, Canada. 


\section{Evaluation of the Neutron Burri-Up cross Section of Tungsten-188}

There is currently widespread interest in the clinical use of rhenium-188 $\left({ }^{188} \mathrm{Re}\right)$ for various medical applications [1-2]. The convenient 16.9 hour half-life and $100 \%$ B emission with high-end point energy $\left(E_{B}{ }^{a v}=764 \mathrm{keV}\right.$ make ${ }^{188} \mathrm{Re}$ an attractive candidate for therapeutic applications. One major advantage is the availability of carrier-free ${ }^{188} \mathrm{Re}$ from the decay of ${ }^{188} \mathrm{~W},\left(t_{1 / 2}=69.4 d\right)$ via our alumina-based generator system [2]. The ${ }^{138} \mathrm{~W}$ parent radionuclide is produced in a nuclear reactor by double neutron capture on highly-enriched ${ }^{186} \mathrm{~W}$. As we have found using the ORNL High Flux Isotope Reactor (HFIR), and others have reported [3], large-scale production yields of ${ }^{188} \mathrm{~W}$ are much lower than theoretical yields by almost one order of magnitude. The cross-sections for the production of the ${ }^{187} \mathrm{~W}$ intermediate radionuclide are well-known. We have found reasonable agreement between the theoretical and experimental yields of ${ }^{187} \mathrm{~W}\left(Y_{\text {theo }} / Y_{\exp }=1.5 \pm 0.3\right)$ [3]. The thin-target production yield of ${ }^{188} \mathrm{~W}$ as a function of irradiation time at a neutron flux of $2 \times 10^{15} \mathrm{n} . \mathrm{s}^{-}$ ${ }^{1} . \mathrm{cm}^{-2}$ (HFIR) is shown in Figure 1 [4] and the cross-section for ${ }^{187} \mathrm{~W}[\mathrm{n}, \mathrm{Y}]^{188} \mathrm{~W}$ reaction is currently under evaluation.

The very high neutron capture cross-section ("burn-up" cross-section) of ${ }^{188} \mathrm{~W}$ is another factor which could be partly responsible for the discrepancy between the experimental and theoretical yields of ${ }^{188} \mathrm{~W}$. Unfortunately, the ${ }^{189} \mathrm{~W}$ radionuclide (formed by neutron capture product of ${ }^{188} \mathrm{~W}$ ) is only poorly known. Since the absolute intensity of the $\mathrm{Y}$-ray from ${ }^{189} \mathrm{~W}$ is not known, in the current studies we report a value for the lower limit of the burn-up cross-section of ${ }^{188} \mathrm{~W}$. In addition, we also describe the results of preliminary data on the decay of ${ }^{189} \mathrm{~W}$ produced via the ${ }^{188} \mathrm{~W}\left(69 \mathrm{~h}, \mathrm{~B}^{-}\right)[\mathrm{n}, \mathrm{Y}]$ reaction. Our attempts to measure the absolute intensity of observed $\mathrm{Y}$-rays were not successful mainly due to the high background from the $B^{-}$radiation of ${ }^{187} \mathrm{~W}$, which is produced by neutron capture of stable ${ }^{186} \mathrm{~W}$ in the target. In addition, high background from the decay of the ${ }^{188} \mathrm{Re}$ decay product of ${ }^{188} \mathrm{~W}$ also interferes with these measurements. 
Prior to irradiation, the assay of radioactivity of the target precipitate and the combined supernates indicated that $>95 \%$ of ${ }^{188} \mathrm{Re}$ was removed from $\mathrm{W}$ in the process, and the $\mathrm{WO}_{3} \bullet \mathrm{nH}_{2} \mathrm{O}$ precipitate typically contained $>80 \%$ of the initial ${ }^{188} \mathrm{~W}$. After irradiation, when $\mathrm{W}$ targets were purified by precipitation, the chemical recovery of $W$ was $\sim 50 \%$. The elapsed time between irradiation and start of counting was about 22 minutes. In two experiments, the targets were counted with no additional chemical separation, and the time period between irradiation and start of counting was about 10 minutes.

ORNL-DWO 9EM-Des5

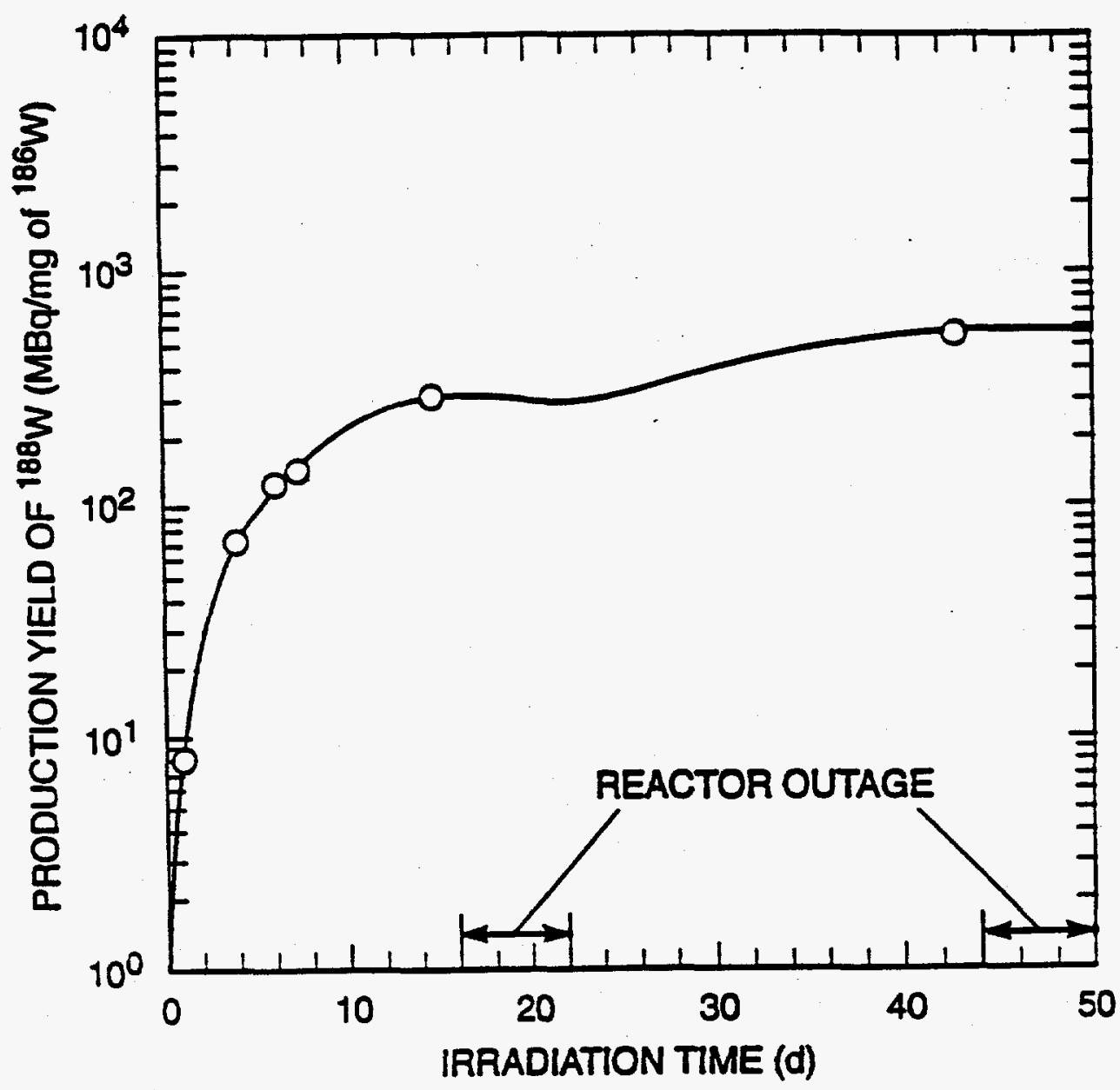

Figure 1. Thin target production yields of tungsten-188 as a function of irradiation time at a thermal neutron flux of $2 \times 10^{15}$ neutrons per second per $\mathrm{cm}^{2}$ in the ORNL HFIR (Data from Ref. [4]). Target mass $=10 \mu \mathrm{g}$ of $\mathrm{W}$ (natural isotopic abundance). The solid curve represents an empirical calculation which accounts for reactor shutdown. 


\begin{tabular}{|c|c|c|c|}
\hline \multicolumn{2}{|c|}{ Table. 1. Gamma-rays Ooserved During Decay of ${ }^{189} \mathrm{~W}$} \\
\hline $\begin{array}{c}\text { From Reference [8] } \\
(\mathrm{keV})\end{array}$ & $\begin{array}{c}\text { IV } \\
(\%)\end{array}$ & $\begin{array}{c}\text { EY } \\
(\mathrm{keV})\end{array}$ & $\begin{array}{c}\text { This Work } \\
(\%)\end{array}$ \\
\hline $94 \pm 5$ & 3 & - & - \\
\hline $130 \pm 2$ & 12 & $130 \pm 2^{\mathrm{b}}$ & - \\
\hline $178 \pm 2$ & 13 & $-\mathrm{a}$ & - \\
\hline $222 \pm 8$ & 3 & $-\mathrm{a}$ & - \\
\hline $258 \pm 3$ & 100 & $260.2 \pm 1.4$ & - \\
\hline $360 \pm 8$ & 10 & $-\mathrm{a}$ & 100 \\
\hline $417 \pm 4$ & 96 & $421.5 \pm 1.6$ & - \\
\hline $550 \pm 10$ & 28 & $545 \pm 3^{\mathrm{b}}$ & - \\
\hline $855 \pm 15$ & 20 & $-a$ & 8 \\
\hline $955 \pm 20$ & 17 & $975 \pm 3$ & \\
\hline
\end{tabular}

a Not observed.

buncertain about assignment to ${ }^{189} \mathrm{~W}$.

The $y$-spectrum of purified ${ }^{189} \mathrm{~W}$ is shown in Figure 2. Only three $y$-rays at $260.1 \pm 1.4$, $421.5 \pm 1.6$ and $975 \pm 3 \mathrm{keV}$ can be attributed to ${ }^{189} \mathrm{~W}$. The decay of these $y$-rays are shown in Figure 3. The 260.1 and $421.5 \mathrm{keV}$ Y-rays have equal intensity, whereas the relative intensity of the $975 \mathrm{keV} Y$-ray is about $8 \%$ (Table 1). Two $Y$-rays at 130 and $545 \mathrm{keV}$ were also observed only in the first two 5-min counts (Figure 2). As shown in Table 2, the weighted average of ${ }^{189} \mathrm{~W}$ half-life obtained from two sets of experiments is $10.8 \pm 0.3 \mathrm{~m}$. The errors associated with the measured $t_{1 / 2}$ in each $y$-ray were used as the weighing factors to obtain the weighted average. Two and half hours post irradiation, the $y$-spectrum of the Re fraction showed a weak signal from $24.3-\mathrm{h}{ }^{189} \mathrm{Re}$ at $216.5 \mathrm{keV}(5.5 \%)$. Due to the high background from the $\aleph^{-}$radiation of ${ }^{187} \mathrm{~W}$ and ${ }^{188} \mathrm{Re}$, no shortlived component could be deduced from the $\beta^{-}$assay of the sample. 


\begin{tabular}{|c|c|c|c|}
\hline Exp. No. & EY $(\mathrm{keV})$ & No. Of Points & $t_{1 / 2}(\%)$ \\
\hline \multirow[t]{2}{*}{ A } & 260.2 & 7 & $9.3 \pm 0.2$ \\
\hline & 421.5 & 3 & $7.2 \pm 0.8$ \\
\hline \multirow[t]{4}{*}{ B } & 260.2 & 5 & $11.9 \pm 0.2$ \\
\hline & 421.5 & 5 & $12.6 \pm 0.3$ \\
\hline & 975 & 4 & $8.0 \pm 0.9$ \\
\hline & \multicolumn{2}{|c|}{ Weighted Average: } & $10.8 \pm 0.2^{\mathrm{a}}$ \\
\hline
\end{tabular}

${ }^{a}$ Error associated with each value is taken as the weighing factor.

A: After irradiation, the $y$-spectrum taken without chemical manipulations.

B: $\quad$ After irradiation, the $y$-spectrum taken of purified target.

Tungsten-189 was initially identified by Flegenheimer, et al. [7] and produced through the ${ }^{192} \mathrm{Os}[\mathrm{n}, \alpha]^{189} \mathrm{~W}$ reaction with fast neutrons $(\sim 14 \mathrm{MeV})$ and a half-life of 11 min was assigned to ${ }^{189} \mathrm{~W}$ by following the $B^{-}$decay of a purified source of ${ }^{189} \mathrm{~W}$. Later, Kauranen and thochi [8], using the same reaction, produced a stronger source and assigned two predominant $y$-rays at 258 and 417 $\mathrm{keV}$ with almost equal intensities ( 100 and $96 \%$, respectively) to ${ }^{189} \mathrm{~W}$. Based on spectra taken using a Nal detector, a number of lower intensity $y$-rays, ranging from 94 to $955 \mathrm{keV}$, were also assigned to ${ }^{189} \mathrm{~W}$ (Table 1). These investigators reported a half-life of $11.5 \pm 0.3 \mathrm{~min}$ for ${ }^{189} \mathrm{~W}$ deduced from the decay of the observed $y$-rays.

In our approach, we produced ${ }^{189} \mathrm{~W}$ by irradiating a radioactive target containing a known amount of ${ }^{188} \mathrm{~W}$. In order to reduce the radiation level to an acceptable level $(<20 \%$ detector dead time), we chemically removed $>90 \%$ of ${ }^{188} \mathrm{Re}$ (the decay product of ${ }^{188} \mathrm{~W}$ ) prior to irradiation. Nevertheless, due to the formation of substantial levels of ${ }^{187} \mathrm{~W}$ which is produced by neutron capture of stable ${ }^{186} \mathrm{~W}$ in the target and in growth of ${ }^{188} \mathrm{Re}$, this results in a continuous increase in the background. We could only confirm the two predominant $y$-rays in the decay of ${ }^{189} \mathrm{~W}$ at 260.1 \pm 1.4 and $421.5 \pm 1.6 \mathrm{keV}$. By following the decay of these $y$-rays in two sets of experiments, a half-life of $10.8 \pm 0.3 \mathrm{~m}$ was obtained for ${ }^{189} \mathrm{~W}$. 

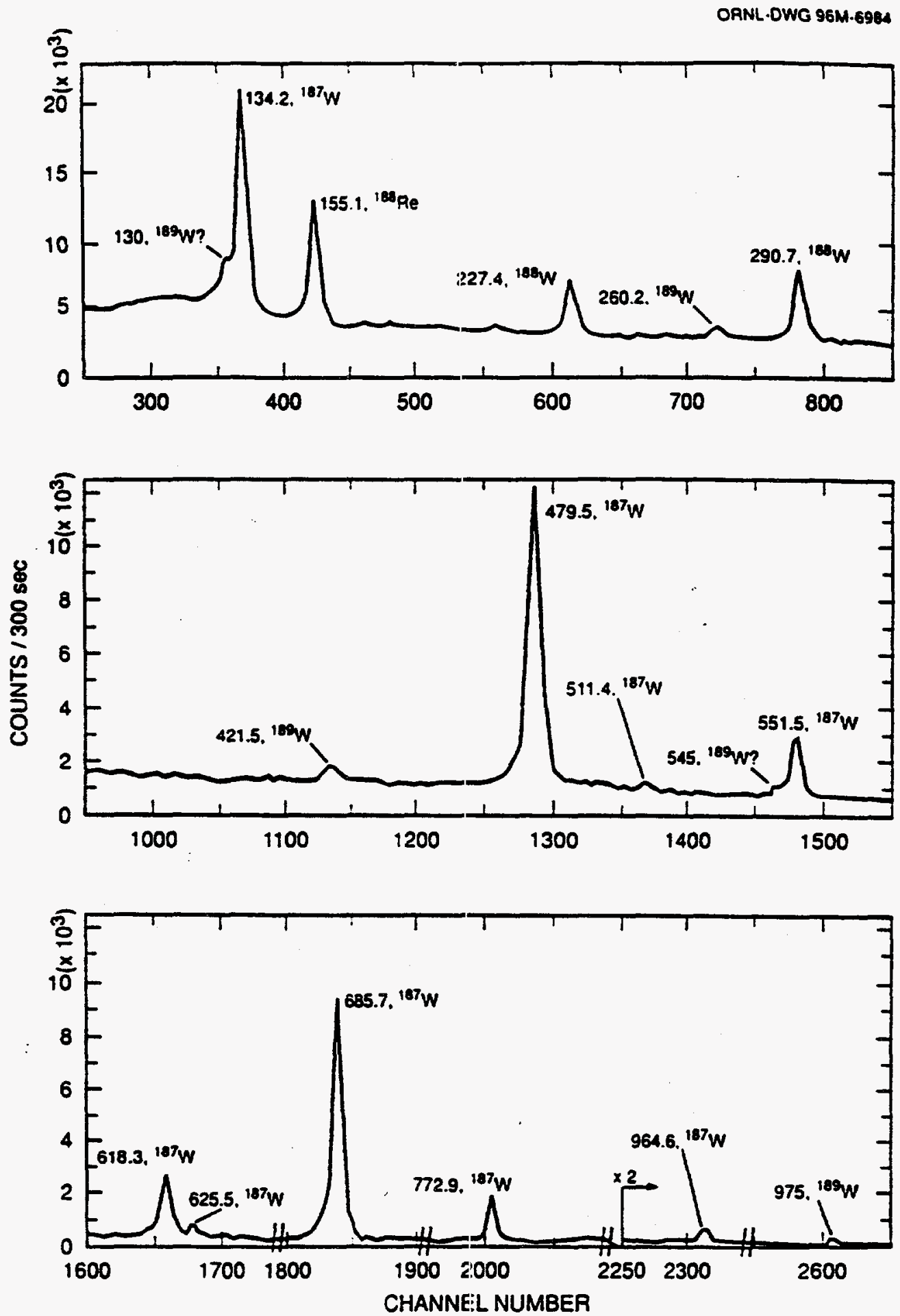

Figure 2. Gamma-ray spectrum of ${ }^{189} \mathrm{~W}$ produced by neutron irradiation of ${ }^{188} \mathrm{~W}$ target. 
From the list of weaker $y$-rays (Table 1), we observed a line at $975 \pm 3 \mathrm{keV}$ which decayed with a $8.0 \pm 0.9 \mathrm{~m}$ half-life. This line is most likely the $955 \pm 20$ line reported earlier [8]. We are uncertain about the assignments of 130 and $545 \mathrm{keV}$ Y-rays to ${ }^{189} \mathrm{~W}$, as these lines are weak and are positioned at the lower edge of two strong signals at $134.2(15 \%)$ and $551.6 \mathrm{keV}(23 \%)$, both from ${ }^{187} \mathrm{~W}$, respectively. Based on a knowledge of the ${ }^{188} \mathrm{~W}$ content of target $(52.6 \mathrm{mBq})$, neutron flux of $5 \times 10^{13} \mathrm{n} . \mathrm{s}^{-1} \cdot \mathrm{cm}^{-2}$, irradiation time of $10 \mathrm{~min}$ and with the assumption of $100 \%$ intensity for 260.1 and $420.5 \mathrm{keV} y$-rays, a cross-section of $12.0 \pm 2.5 \mathrm{~b}$ was calculated for the burn-up crosssection of ${ }^{188} \mathrm{~W}$.

These results are important since they help explain the discrepancy reported earlier $[9,10]$ between the calculated and observed production yields for tungsten-188 by irradiation of tungsten186. Even though we had developed processing methods for the complete dissolution of either enriched tungsten-186 metal or oxide targets, the production values have consistently been nearly. an order of magnitude lower than those calculated. Our demonstration of the significant burn-up cross section for tungsten-188 will now provide an opportunity to further develop our computer code to iterate the expected production yields of tungsten-188 in the HFIR. 
$\stackrel{+}{-1}$

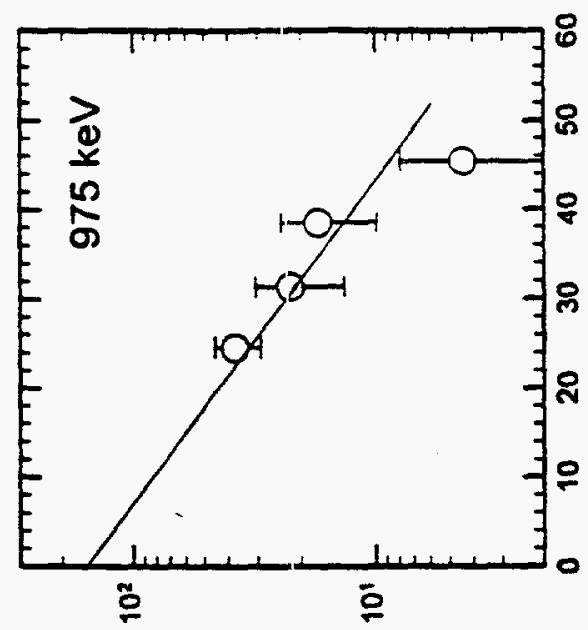

ఖ

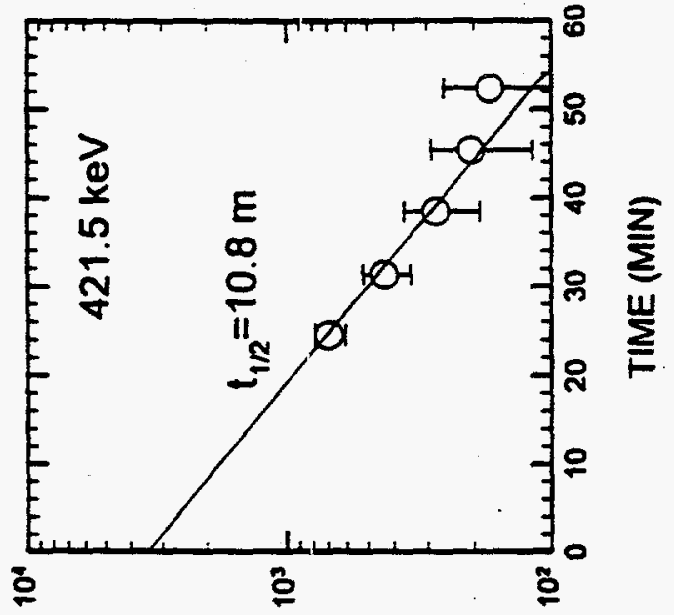

통

a

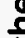

亭

ปั

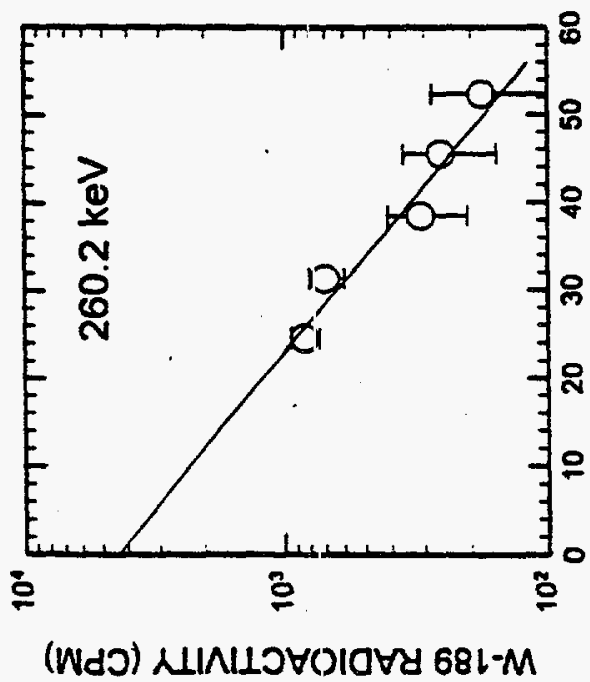

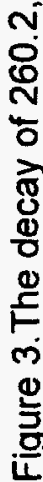




\section{LITERATURE CITED}

1. Zamora, P. O., Gulhke, S., Bender, H., Diekmann, D., Rhodes, B. A., Biersack, H.-J., and Knapp, Jr., F. F. "Experimental Radiotherapy of Receptor-positive, Human Prostate Adenocarcinoma with ${ }^{188} \mathrm{Re}-\mathrm{RC}-160$, A Directly-radiolabeled Somatostatin Analogue," Int. J. Cancer, 65, 214 (1996).

2. Kamioki, H., Mirzadeh, S., Lambrecht, R. M., Knapp, Jr., F. F., and Dadachova, E. ${ }^{1188} \mathrm{~W} \rightarrow{ }^{188} \mathrm{Re}$ Generator for Biomedical Applications," Radiochimica Acta, 65, 39 (1994).

3. Callahan, A. P., Mirzadeh, S. and Knapp, Jr., F. F. "Large Scale Production of Tungsten188". Proceedings, Symposium on Radionuclide Generator Systems for Medical Applications, Am. Chem. Soc., Washington D.C., August 24-28, 1992; Radioactivity and Radiochemistry, 3, 46 (1992).

4. Mirzadeh, S. and Marsh, D. "Neutron Capture Cross-sections of ${ }^{187} \mathrm{~W}$ and ${ }^{188} \mathrm{~W}^{\prime \prime}$, Unpublished.

5. Knapp, Jr., F. F., et al, Nuclear Medicine Group Progress Report ORNLTM-12485, p23. September (1993).

6. Cummings, J. B., National Academy of Sciences-National Research Council, Nuclear Science Series, Report No. NAS-NS-3107 (1962).

7. Flegenheimer, J., Baro, G. B., and Viirsoo, M. "The ${ }^{189} \mathrm{~W}-{ }^{189}$ Re Decay Chain", Radiochim Acta, 2, 7 (1963).

8. Kauranen, P. and Ihochi, H. "The Decay of ${ }^{189}$ W," J. Inorg. Nucl. Chem., 27, 1451 (1964). 
9. Knapp, Jr., F. F., Callahan, A. P., Beets, A. L., Mirzadeh, S., and Hsieh, B.-T. "Processing of Reactor-Produced ${ }^{188} \mathrm{~W}$ for Fabrication of Clinical Scale Alumina-Based ${ }^{188} \mathrm{~W} /{ }^{188} \mathrm{Re}$ Generators," Appl. Radiat. Isot., 45 (12), pp. 1123-1128 (1994).

10. Knapp, Jr., F. F., Mirzadeh, S., and Beets, A. L. "Reactor Production and Processing of Therapeutic Radioisotopes for Applications in Nuclear Medicine," J. Radioanalytical and Nucl. Chem., Articles, 205 (1), pp. 93-100 (1996).

\section{Other Nuclear Medicine Group Activities}

\section{Medical Cooperative Programs}

During this period, several radioisotopes, generators, and other medical radioisotopes were provided to collaborators for joint research, including tungsten-188/rhenium-188 generators which were provided to the Department of Interventional Cardiology (J. Wienberger, M.D.), Columbia University, New York, and the Department of Nuclear Medicine (J. Kropp, M.D.), The University Hospital, Dresden, Germany. Platinium-193m was provided to the Clinic for Nuclear Medicine (S. N. Reske, M.D.), The University of Ulm, Germany, for a collaborative project focused on evaluating the kinetics of uptake into ovarian cancer cells refractive to cis-DDP therapy.

\section{Distribution of Radioisotopes By Cost Recovery Through the ORNL Isotopes Distribution Office (IDO)}

Medical radioisotopes which were provided for full cost recovery through the ORNL Isotope Production and Distribution Program included a sample of tungsten-188 provided to Nordion, Inc., and high specific activity rhenium-186 which was sold to Mallinckrodt Medical, Petten, Holland. A tungsten-188/rhenium-188 generator was provided to Altarex, Inc., Alberta, Canada. 


\section{Recent Publications}

1. Lin, H., Luo, H. Mokler, F., Knapp, Jr., F. F., Beets, A. L., Ambrose, K. R., McPherson, D. W., and Kroff, J. "Effects of Configuration on the Myocardial Uptake of Radioiodinated 3(R)-BMIPP and 3(S)-BMIPP," J. of Nucl. Med., submitted.

2. Knapp, Jr., F. F., McPherson, D. W., Luo, H., and Zeeburg, B. "Radiolabeled Ligands for Imaging the Muscarinic-Cholinergic Receptors of the Heart and Brain," AntiCancer Research, submitted.

\section{Meetings}

\section{American Chemical Society}

A Symposium entitled, "Radiochemistry and Radioimmunotherapy" was recently organized by S. Mirzadeh, F. F. (Russ) Knapp, Jr., and S. J. Kennel in association with the Biannual Meeting of the American Chemical Society, Orlando, Florida, August 25-28, 1996. Twenty-four technical papers were organized in three scientific sessions. The "Proceedings" of this Symposium will be published in a special issue of Radiochimica Acta.

1. Alberto, R., Schibli, R., Egli, A., Schubiger, P. A., and Knapp, Jr., F. F. "Potential of the Organometallic "[M(CO) $)_{3}^{++1}(M=R e, T c)$ Fragment for the Labeling of Proteins and Small Molecules."

2. Kennel, S. J. and Mirzadeh, S. "Vascular Targeting for Radioimmunotherapy with Bismuth213."

3. Mirzadeh, S. and Kennel, S. J. "Optimizations of Radiolabeling of Immunoproteins with Bismuth-213."

4. Verdera, E. S., Gaudiano, J., Leon, A., Martinez, G., Robles, A., Savio, E., Leon, E., McPherson, D. W., and Knapp, Jr., F. F. "Rhenium-188 HEDP - Kit Formulation /Quality Control."

5. Zamora, P. O., Guhlke, S., Rhodes, B. A., Marek, M. J., Bender, H., Biersack, H.-J., and Knapp, Jr., F. F. "Radiotherapy Using Re-188-Labeled RC-160 peptide." 


\section{Participation in Bone Pain Palliation Symposium}

Members of the ORNL Nuclear Medicine Program were invited to present two talks at the recent "Symposium for Radionuclides Used in Bone Fain Palliation Therapy," held under the auspices of the Council on Ionizing Radiation Measurements and Standards (CIRMS), at the National Institute for Standards and Technology (NIST), Gaithersburg, Maryland, September 27, 1996. The "Proceedings" of this Symposium will also be published in a special publication.

1. Mirzadeh, S. "Generator-Produced Alpha-Emitting Radioisotopes."

2. Knapp, Jr., F. F. "Reactor-Produced Radionuclides from the ORNL-HFIR for Treatment of Bone Pain."

\section{Participation in International Congress}

D. W. McPherson and F. F. (Russ) Knapp, Jr., participated in the European Association of Nuclear Medicine (EANM) Congress, held in Copenhagen, Denmark, September 14-18, 1996. Following the Congress, they also participated in the "Post Congress" Symposium on "Radiolabeled Peptides," Oslo, Norway, September 19-20. Following the EANM Congress, F. F. Knapp also visited the Nuclear Medicine Department at the University of Bonn, Germany, to coordinate ongoing collaborative studies and to participate in a Breast Cancer Symposium. He also visited Mallinckrodt Medical, Petten, Holland, and presented a seminar on the development and clinical applications of the ORNL tungsten-188/rhenium-188 generator, and to discuss the commercial availability of medical radioisotopes from ORNL.

1. Bergstrom, K. A., Halldin, C., Hall, H., Hiltunen, J., Ito, H., Ginovart, N., Swahn, C.-G., McPherson, D. W., Knapp, F. F., Jr., Larsson, S., Schnell, P. O. and Farde, L.," In Vitro Characterization and In Vivo Metabolic Studies with I-125 and I-131 Labeled E-(-,-)-IQNP: A New Radioligand for Visualization of $M_{1}$ Muscarinic Acetylcholine Receptor in Brain." 
ORNL/TM-13328

\section{INTERNAL DISTRIBUTION}

1. C. W. Alexander

2. A. L. Beets

3. B. A. Berven

4. R. Boll

5. E. D. Collins

6. K. F. Eckerman

7-10. F. F. Knapp, Jr.

11. H. Luo

12. D. W. McPherson

13. S. Mirzadeh

14. B. Patton
15.

16.

17.

18.

19-21.

22.

23-25.

26.

27.
D. E. Reichle

P. S. Rohwer

R. E. Swaja

S. J. Wolfe

Central Research Library

Document Record Section

Laboratory Records Dept

Lab Records, ORNL - RC

ORNL Patent Section

\section{EXTERNAL DISTRIBUTION}

28. K. Ambrose, 1220 Timbergrove Drive, Knoxville, TN 37919

29. H. L. Atkins, M.D., Radiology Dept., State Univ. of New York, Stony Brook, NY 11794-8460

30. H-J. Biersack, M.D., Director, Klinik fuer Nuklear Medizin, Der Universitaet Bonn, Sigmund Freud Strasse 25, 53127, Bonn 1, Germany

31. P. J. Blower, Kent and Canterbury Hospital, NHS Trust, Ethelbert Road, Canterbury, England CT1 3NG

32. A. Bockisch, Ph.D., M.D., Klinik und Poliklinik fuer Nuklearmedizin, Hufelanderstrasse 55, D-45122, Essen, Germany

33. C. Brihaye, Centre de Recherches du Cyclotron, Universite de Liege, Belgium

34. A. B. Brill, M.D., Ph.D., Dept. of Nuclear Medicine, Univ. of Massachusetts Medical Center, 55 Lake Avenue North, Worcester, MA 01655

35. T. F. Budinger, M.D., MS 55/121, Lawrence Berkeley Laboratory, 1 Cyclotron Road, Berkeley, CA 94720

36. A. P. Callahan, 534 Colonial Drive, Harriman, TN 37748

37. J. S. Carty, Isotope Production and Distribution Program, U.S. Department of Energy, NE46, GTN, Room B-419, Washington, DC 20585-1290

38. D. Cole, Medical Applications and Biophysical Research Division, ER-73, Department of Energy, GTN, Washington, DC 20585-1290

39. B. Coursey, National Institute for Standards and Technology, Building 245, RM C214 Gaithersburg, MD 20899

40. J. G. Davis, M.D., Medical and Health Sciences Division, ORAU, Oak Ridge, TN 37831

41. R. F. Dannals, Division of Nuclear Medicine, Johns Hopkins Medical Institutions, Baltimore, MD 21205-2179

42. S.J. DeNardo, M.D., University of California, Davis Medical Center, 4301-X Street, FOCB II-E Sacramento, CA 95817

43. R. Dudczak, M.D., Dept. Nuclear Medicine, I. Medizinische Universitatsklinik, A-1090 Wien, Lazarettgasse 14, Vienna, Austria 
44. G. Ehrhardt, Missouri University Research Reactor, University of Missouri, Research Park, Columbia, MO 65211

45. D. R. Elmaleh, Physics Research Dept., Massachusetts General Hospital, Boston, MA 02114

46. L. Feinendegen, Medical Department, Brookhaven National Laboratory, Upton, NY 11973

47. J. Fowler, Chemistry Department, Brookhaven National Laboratory, Upton, NY 11973

48. A. Fritzberg, NeoRx Corporation, 410 West Harrison, Seattle, WA 98119

49. D. M. Goldenberg, M.D., Center of Molecular Medicine and Immunology, 1 Bruce Street, Newark, NJ 07103

50. G. Goldstein, DOE-OHER, Washington, DC 20585

51. M. M. Goodman, Emory Center for Positron Emission Tomography, 1364 Clifton Road, N.E., Atlanta, Georgia 30322

52. G. Griffiths, Immunomedics, Inc., 300 American Rd, Morris Plains, NJ 07950

53. S. Guhlke, Klinik fuer Nuklear Medizin, Der Universitaet Bonn, Sigmund Freud Strasse 25, 53127, Bonn 1, Germany

54. J. Hiltunen, Managing Director, MAP Medical Technologies, Inc., Elementtitie 27, SF-41160 Tikkakoski, Finland

55. R. Holmes, M.D., Director, Research \& Development, DuPont Merck Pharmaceutical Company, 331 Treble Cove Rd., North Billerica, MA 01862

56. Bor-Tsung Hsieh, Ph.D., Institute of Nuclear Energy Research, (INER) Lung-Tan, Taiwan, Republic of China

57. K. Hubner, M.D., Department of Radiolıgy, UT Memorial Hospital, Knoxville, TN 37920

58. J. M. R. Hutchinson,Ph.D., U. S. Dept. of Commerce, National Institute of Standards and Technology, Gaithersburg, MD 20899-(1001

59. B. Johannsen, Ph.D., Forschungszentrum Rossendorf e.V.Postfach 5101 19, D-01314 Dresden, Federal Republic of Germany

60. A. Jones, HMS Radiology Dept., Shield!s Warren Radiation Laboratory, 50 Binney Street, Boston, MA 02115

61. G. W. Kabalka, Chemistry Department, University of Tennessee, Knoxville, TN 37996-1600

62. G. Kirsch, Department of Chemistry, Uriversite de Metz, Metz, France

63. J. Kropp, M.D., Klinik fur Nuklearmedizin, der Medizinischen Akademie, Fetscher - Str. 74, 01307 Dresden, Germany

64. R. A. Kuznetsov, Rostislav A. Kuznetsov, Laboratory of Radiochemical Processing, State Scientific Centre of Russia, Division of Radionuclide Sources and Preparations, Dimitrovgard-10, Ulyanovsk Region, 43:3510 Russia

65. R. Lambrecht, Ph.D. Pet-Zentrum des Universitaetsklinikum, Eberhard-Karls-Universitaet Tuebingen, 15 Roentgenweg, Tuebingen 72076, Germany

66. S. Larson, M.D., Sloan-Kettering Inst. for Cancer Research, New York, NY 10021

67. Q. Lin, Ph.D., Chemistry Department, Xavier University, New Orleans, Louisiana

68. E. C. Lisic,Ph.D., Department of Chiemistry, Tennessee Technological University, Cookeville, TN 38505

69. J. Lister-James, Ph.D., Director, Research Administration, Diatech, Inc., 9 Delta Drive, Londonderry, NH 03053

70. O. Lowe, Isotope Production and Distribution Program, U.S. Department of Energy, NE-46, GTN, Room B-419, Washington, DC 20585-1290

71. G. Limouris, Nuclear Medicine Department, Areteion University Hospital, Athens Medical School, Athens, Greece 
72. D. J. Maddalena, FRACI, Department of Pharmacology, Sydney University, NSW 2006, Sydney, Australia

73. John Maddox, 4608 Flower Valiey Drive, Rockville, MD 20853-1733

74. H.-J. Machulla, Eberhard-Karls-Universität Tübingen, Radiologische Universitätsklinik, PetZentrum, Röntgenweg 11, 7400 Tübingen, Germany

75. Frederick J. Manning, National Academy of Sciences, Institute of Medicine, 2101 Constitution Ave., M.W., Washington, DC 20418

76. Office of Assistant Manager for Energy Research and Development DOE-ORO, Oak Ridge, TN 37831

77. G. Notohamiprodjo, M.D., Ph.D., Institute of Nuclear Medicine, Heart Center North RhineWestphalia, Bad Oeynhansen, D-4970, Germany

78. C. L. Partain, M.D., Professor and Vice Chairman, Dept. Radiology and Radiological Sciences, Vanderbilt University Medical Center, Nashville, TN 37232

79. R.C. Reba, Dept. of Radiology, 5841 S. Maryland Ave., MC 2026, Chicago, IL 60637

80. S. N. Reske, M.D., Klinik für Nuklearmedizin, Arztlicher Direktor der Nuklearmedizin, Klinikum der Universität Ulm Oberer Eselsberg, D-7900, Ulm, Germany

81. M. P. Sandler, M.D., Chief, Nuclear Medicine Section, Vanderbilt University Medical Center, Nashville, TN 37232

82. R. E. Schenter, HO-37, Westinghouse Hanford Co., P.O. Box 1970, Richland, WA 99352

83. A. Serafini, Nuclear Medicine Division (D-57), University of Miami School of Medicine, P. O. Box 016960, Miami, FL 33101

84. S. K. Shukla, Prof., Servizio Di Medicina Nucleare, Ospedale S. Eugenio, Pizzale Umanesimo, 10, Rome, Italy

85. S. Smith, Biomedicine \& Health Program, Australian Nuclear Sci. \& Tech. Org., Lucas Heights Research Laboratories, Private Mail Bag 1, Menai NSW 2234, Australia

86. A. Solomon, M.D., UT MRCH, 1924 Alcoa Highway, Knoxville, TN 37920-6999

87. P. Som, DVM, Medical Department, BNL, Upton, NY 11973

88. P. C. Srivastava, DOE-OHER, Washington, DC 20585

89. S. C. Srivastava, Bldg. 801, Medical Dept., BNL, Upton, NY 11973

90. G. Strathearn, Isotope Products Laboratories, Inc., 3017 N. San Fernando BIvd., Burbank, CA 91504

91-92. Office of Scientific and Technical Information, DOE, Oak Ridge, TN 37831

93. E. A. van Royen, M.D., Ph.D., Head, Department of Nuclear Medicine, Academic Medical Center, University of Amsterdam, Meibergdreef 9, 1105 AZ Amsterdam ZO, The Netherlands

94. F. C. Visser, M.D., Cardiology Dept., Free University Hospital, De Boelelaan 117, Amsterdam, The Netherlands

95. H. N. Wagner, Jr., M.D., Division of Nuclear Medicine, Johns Hopkins Medical Institutions, 615 N. Wolfe Street, Baltimore, MD 21205-2179

96. R. Wolfangel, Mallinckrodt, Inc., 675 McDonnell Blvd., P.O. Box 5840, St. Louis, MO 63134

97. J.-I. Wu, Ph.D., Senior Research Representative, Nihon Medi-Physics Co., Ltd., 2200 Powell Street, Suite 765, Emeryville, CA 94608

98. S. Wynchank, Research Institute for Medical Biophysics (RIMB), Republic of South Africa

99. Y. Yonekura, M.D., Fukui Medical School, 23 Shimoaizuki, Matsuoka, Fukui 910-11, Japan 